\title{
Impact of Anthelmintic against Naturally Infected Gastrointestinal Nematodes in Ruminants of Budgam District, Jammu and Kashmir, India
}

\author{
Kamal Hashan Bulbul ${ }^{1}$, Syed Shanaz Shaf ${ }^{1}$, Dilruba Hasin ${ }^{2}$, Afzal Hoque Akand ${ }^{3}$, \\ Nazir Ahmad ${ }^{1}$ and Islam Uddin Sheikh ${ }^{3}$
}

${ }^{1}$ Krishi Vigyan Kendra, Budgam, Jammu and Kashmir, India

${ }^{2}$ KVK Srinagar, Jammu and Kashmir, India

${ }^{3}$ Sher-e-Kashmir University of Agricultural Sciences and Technology of Kashmir, Jammu and Kashmir, India

*Corresponding author

\begin{abstract}
A B S T R A C T
Before perform any parasitological examination, a pre-requisite questionnaire was used to collect data from the 100 livestock holder of district Budgam, Jammu and Kashmir to evaluate the knowledge about the use of anthelmintic against worm infestation in

\begin{tabular}{|c|}
\hline Keywords \\
\hline $\begin{array}{l}\text { GI nematodes, } \\
\text { Ruminants, } \\
\text { Anthelmintic, } \\
\text { FECR\% }\end{array}$ \\
\hline Article Info \\
\hline $\begin{array}{l}\text { Accepted: } \\
\text { 20 February } 2018 \\
\text { Available Online } \\
10 \text { March } 2018\end{array}$ \\
\hline
\end{tabular}
ruminants. The study revealed that $83.00 \%$ respondent was aware of deworming and $92.00 \%$ respondent unaware of purpose of faecal examination of their livestock. Hence, a total of 537 faecal samples comprising of 159 (cattle), 133 (sheep) and 245(goat) was collected randomly from 5 no. of villages of the study areas to record the occurrence of gastrointestinal nematodes. The coprological examination revealed overall occurrence of gastrointestinal nematodes was found to be $81.13,84.96$ and 88.98 per cent in cattle, sheep and goats, respectively. Haemonchus sp. was common in cattle $(30.18 \%)$ and sheep (30.82\%), but in case of goat it was Trichostrongylus sp. (24.08\%). The other parasites were found to be Oesophagostomum, Cooperia, Bunostomum and Trichuris. When administered ivermectin (Inj. Ivomec) @ $200 \mu \mathrm{g} / \mathrm{kg} \mathrm{BW}$ subcutaneously, Ivermectin bolus (Endectin)@ $200 \mu \mathrm{g} / \mathrm{kg} \mathrm{BW}$ orally, Albendazole suspensions (Albomar) @ 7.5mg/kg BW orally and Fenbendazole (Fentas Bolus) @7.5mg per Kg BW orally the faecal egg count reduction per cent (FECR\%) was found to be in sheep 98.86+1.04, 97.70+1.42, $80.72+2.18,85.71+5.04$; in goats $96.39+1.52,97.56+1.94,86.05+3.82$ and $85.06+4.52$ and in cattle $88.37+5.23,90.00+8.75,79.59+6.67$ and $76.60+8.56$ in group $\mathrm{A}, \mathrm{B}, \mathrm{C}$ and $\mathrm{D}$, respectively on $14^{\text {th }}$ day of post-treatment.
\end{abstract}

\section{Introduction}

Krishi Vigyan Kendra (KVK) are in very much active in different districts of Jammu and Kashmir to aware various aspect like imparting training programme, dissemination of latest technologies of SKUAST, on farm trial, front line demonstration, disease diagnostic visit etc. (Bulbul et al., 2014; Bulbul et al., 2015) to uplift the rural economy. Most of the livestock holder lost their economy in terms of production and productivity of ruminants due to lack of some knowledge on various diseases and their 
prevention. Among the various disease producing organisms, gastrointestinal nematodes play a significant role in great economic losses to livestock through morbidity, mortality and reduce productivity (Hoste et al., 2008). So, the cumulative effect of parasitism in terms of mortality, morbidity, chronic diseases and economic losses are incalculatably great and undoubtedly play a key role in limiting the social and economic development of many sub-tropical and tropical countries of the world. Moreover, the GI parasitic infection in dairy animals is neglected due to the chronic nature of parasitism, but results are significant loss of production.

Therefore anti-parasitic drugs are used to control the parasitic diseases. In field condition more or less most of the para-vets either knowingly or unknowing use same group of anthelmintic regularly, use of anthelmintics in sub-optimal doses, prophylactic mass treatment of domestic animals and frequent and continuous use of a single drug as a result anthelmintic resistance (AR) is widespread worldwide (Kaplan, 2004). Hence, the present study was planned to assess knowledge level of the livestock holder on use of anthelmintic and gastrointestinal parasitism and to determine the occurrence of GI nematodes in cattle, sheep and goat and the therapeutic efficacy of different anthelmintics against naturally infected gastrointestinal nematodosis in ruminants.

\section{Materials and Methods}

A pre-requisite questionnaire was prepared to evaluate the knowledge about use of anthelmintic against worm infestation in five different villages viz. Narkara, Kralpora, Rawolpora, Badipora and Banderpora of Budgam district of Jammu and Kashmir. After that a total of 537 faecal samples comprising of 159 (cattle), 133 (sheep) and 245(goat) irrespective of sex and age was collected per rectally randomly from the study areas to record the occurrence of gastrointestinal nematodes. The collected faecal samples were examined by the method of sedimentation and floatation to record the occurrence nematodosis (Soulsby, 1982). The unidentified eggs were cultured for the development of $3^{\text {rd }}$ stage larvae and identified as per the method of Roberts and O'Solivan (1949).

\section{Faecal egg count reduction test}

Thirty sheep showing > 500 egg per gram (EPG); 30 goats having > 500 EPG and 30 cattle showing 150-700 EPG of GI nematodes at farmers flock were selected for conducting the efficacy trial of different anthelmentics. The study was performed using the faecal egg count reduction per cent (FECR\%) over a period of 14 days of post treatment as described by Coles (1992). The selected animals were divided in to five equal treatment groups viz. A, B, C, D and E for each species. Ivermectin (Inj. Ivomec) @ 200 $\mu \mathrm{g} / \mathrm{kg}$ BW subcutaneously, Ivermectin bolus (Endectin) @ $200 \mu \mathrm{g} / \mathrm{kg}$ BW orally, Albendazole suspensions (Albomar) @ $7.5 \mathrm{mg} / \mathrm{kg}$ BW orally and Fenbendazole (Fentas Bolus) @7.5mg per Kg BW orally were administered in animals of $\mathrm{A}, \mathrm{B}, \mathrm{C}$ and $\mathrm{D}$, respectively while animals of group ' $\mathrm{E}$ ' was kept as untreated control. To determine the FECR\% of GI nematodes in animals, faecal sample of each animal in the respective treatment groups were collected per rectal method in the morning hour, starting from 0 day i.e. in pre-treatment and $7^{\text {th }}$ and $14^{\text {th }}$ day of post- treatment. The egg per gram (EPG) of faecal samples was performed by dilution technique (Soulsby, 1982) on pre-treatment and post-treatment. Faecal egg count reduction percent (FECR \%) and efficacy was calculated by using the following formula. 
Pre-treatment EPG — Post-treatment EPG FECR $(\%)=-\frac{-}{\text { Pre-treatment EPG }}$

\section{Results and Discussion}

\section{Knowledge level}

The knowledge level of the livestock holder has been depicted in Table 1 . The study revealed that 75.00 and $83.00 \%$ livestock was aware of parasitic diseases and deworming, respectively and 92\% respondent expressed their view regarding unaware of purpose of faecal examination of their livestock. The study exposed that 85.00 and $65 \%$ livestock holder saw the bottle jaw in animals and reduces milk yield, rough body coat, diarrhoea, constipation etc. in same animal, respectively. Eighty nine per cent livestock keeper expressed when the para-vets were visited for any treatment they administered anti-parasitic drugs every times. Although the livestock holder found to have been aware regarding parasitic diseases and their deworming practices in ruminants, higher incidence of GI nematodes is still prevailed in the area.

This possible explanation may be contributed by the fact of different associated husbandry practices, pasture larvae burden, anthelmintic resistance etc. The similar findings were also reported by Bulbul et al., (2014) who recorded $92.50 \%$ farmers were aware of deworming in Kashmir valley. The differences of the knowledge level might be due to sample sizes and method of collection of data. Almost each and every farmers did not follow any deworming schedule was reflected in our present study.

\section{Coproexamination}

The parasitological examination revealed that $460(85.66 \%)$ animals were found to be positive for GI nematodosis. Overall occurrence of gastrointestinal nematodosis was found highest in goats $(88.98 \%)$ followed by sheep $(84.96 \%)$ and cattle $(81.13 \%)$.

The occurrence of GI nematodosis was found to be recorded $81.13 \%$ in cattle with the prevalence of Haemonchus sp. was maximum (30.18\%) followed by Trichostrongylus sp. (13.20\%), Oesophagostomum sp. (10.16\%), Bunostomum sp. (4.40\%) and Cooperia sp. (3.14\%), Ascaris sp. (5.03\%), Trichuris sp. (3.77\%), Strongyloides sp. (2.51\%) and mixed infection of strongyle and others $(8.17 \%)$.

In contrast to our findings Borthakur and Das (1998) in Assam, Palampalle et al., (2002) in Maharastra also observed similar pattern of GI nematodosis in cattle.

In case of sheep, highest incidence was found to be of Haemonchus sp. (30.82\%) followed by Trichostrongylus sp. (11.27\%), Strongyloides sp. (9.77\%), Marshallagia sp. (6.77\%), Oesophagostomum sp. (5.26\%), Trichuris sp. (3.76\%) Bunostomum sp. (3.01\%) and Cooperia sp. (2.25\%).

Mixed infection was seen in only $12.03 \%$ samples. These findings were almost corrobated with the findings of Dhar and Sharma (1982) and Khajuria and Kapoor (2003). Makhdoomi et al., (1995) have also reported similar findings in sheep in Kashmir valley.

In case of goats, maximum $24.08 \%$ cases were found to be of Trichostrongylus sp. followed by Haemonchus sp. (15.51\%), Strongyloides sp. (10.20\%), Oesophagostomum sp. (9.39\%), Nematodirus sp. (6.94\%), Marshallagia sp. (3.67\%), Trichuris sp. (3.27\%) Cooperia sp. (2.86\%) and Bunostomum sp. (2.04\%) while mixed infection was11.02 per cent. These finding are quite similar to the findings of Singh et al., (1999). 
Table.1 Knowledge level of livestock holder on parasitic diseases

\begin{tabular}{|l|l|l|l|}
\hline SI. No. & \multicolumn{1}{|c|}{ Statements } & Yes & No \\
\hline 1 & $\begin{array}{l}\text { Do you know about parasitism or parasitic infection } \\
\text { Have you seen bottle jaw in your animals }\end{array}$ & 75 & 25 \\
\hline 3 & $\begin{array}{l}\text { Have you seen reduce milk yield, rough body coat, diarrhoea, } \\
\text { constipation etc. in same animal }\end{array}$ & 85 & 15 \\
\hline 4 & $\begin{array}{l}\text { Do you know about the deworming/ dosing schedule } \\
\text { How many time have you administered anthelmintic drugs } \\
\text { (during last one year) }\end{array}$ & 35 \\
\hline 5 & Not remember & 17 \\
\hline b & 1 time & 50 & 50 \\
\hline c & $\begin{array}{l}\text { 2 times } \\
\text { d }\end{array}$ & 4 & 96 \\
\hline 3-4 times & 13 & 87 \\
\hline 6 & $\begin{array}{l}\text { Did the para-vets administered anthelmintics every times they } \\
\text { visited your farm to treat the animals }\end{array}$ & 72 & 28 \\
\hline 7 & $\begin{array}{l}\text { Do you know the what purpose faecal samples of animals done } \\
\text { Have you got any advice from para-vets to test faecal samples }\end{array}$ & 8 & 11 \\
\hline
\end{tabular}

Figures are in frequency and equivalent to per cent (Sample size 100)

Table.2 Efficacy of anthelmentics against naturally acquired nematodosis

\begin{tabular}{|c|c|c|c|c|c|}
\hline \multirow[t]{3}{*}{ Group } & \multirow{3}{*}{$\begin{array}{l}\text { Pre-treatment } \\
\text { 0 day } \\
\text { EPG }\end{array}$} & \multicolumn{4}{|c|}{ Post-treatment } \\
\hline & & \multicolumn{2}{|c|}{$7^{\text {th }}$ Day } & \multicolumn{2}{|c|}{$14^{\text {th }}$ day } \\
\hline & & EPG \pm SE & FECRT $\% \pm \mathbf{S E}$ & EPG $\pm S E$ & FECRT $\% \pm \mathbf{S E}$ \\
\hline \multicolumn{6}{|l|}{ Sheep } \\
\hline $\mathbf{A}$ & $733.33+60.10$ & $200.00 \pm 28.87$ & $72.72 \pm 3.94$ & $8.33 \pm 8.34$ & $98.86 \pm 1.04$ \\
\hline $\mathbf{B}$ & $725.00 \pm 38.20$ & $233.33 \pm 27.89$ & $67.82 \pm 4.14$ & $16.67 \pm 10.54$ & $97.70 \pm 1.42$ \\
\hline $\mathrm{C}$ & $691.67 \pm 50.70$ & $158.33 \pm 32.71$ & $77.11 \pm 4.67$ & $133.33 \pm 16.67$ & $80.72 \pm 2.18$ \\
\hline $\bar{D}$ & $758.33 \pm 66.37$ & $166.67 \pm 33.34$ & $78.02 \pm 4.99$ & $108.33 \pm 35.17$ & $85.71 \pm 5.04$ \\
\hline $\mathbf{E}$ & $658.33 \pm 55.41$ & $683.33 \pm 60.10$ & $-3.80 \pm 3.50$ & $758.33 \pm 47.30$ & $-15.19 \pm 3.87$ \\
\hline \multicolumn{6}{|l|}{ Goats } \\
\hline $\mathbf{A}$ & $691.67 \pm 75.75$ & $200.00 \pm 34.16$ & $71.08 \pm 3.79$ & $25.00 \pm 11.18$ & $96.39 \pm 1.52$ \\
\hline B & $683.33 \pm 55.79$ & $216.67 \pm 24.73$ & $68.29 \pm 3.22$ & $16.67 \pm 10.54$ & $97.56 \pm 1.94$ \\
\hline $\mathrm{C}$ & $716.67 \pm 61.48$ & $225.00 \pm 33.55$ & $68.60 \pm 3.66$ & $100.00 \pm 25.83$ & $86.05 \pm 3.82$ \\
\hline D & $725.00 \pm 42.34$ & $233.33 \pm 35.75$ & $67.82 \pm 5.41$ & $108.33 \pm 35.17$ & $85.06 \pm 4.52$ \\
\hline $\mathbf{E}$ & $633.33 \pm 57.26$ & $675.00 \pm 42.34$ & $-6.58 \pm 2.97$ & $758.33 \pm 30.05$ & $-19.74 \pm 5.47$ \\
\hline \multicolumn{6}{|l|}{ Cattle } \\
\hline $\mathbf{A}$ & $358.33 \pm 65.10$ & $133.33 \pm 27.89$ & $62.79 \pm 3.79$ & $41.67 \pm 15.37$ & $88.37 \pm 5.23$ \\
\hline $\mathbf{B}$ & $333.33 \pm 89.15$ & $108 . \pm 20.07$ & $67.50 \pm 8.56$ & $33.33 \pm 16.67$ & $90.00 \pm 8.75$ \\
\hline $\mathrm{C}$ & $408.33 \pm 62.48$ & $158.33 \pm 32.71$ & $61.24 \pm 9.36$ & $83.33 \pm 27.89$ & $79.59 \pm 6.67$ \\
\hline D & $391.6667 \pm 39.62$ & $158.33 \pm 32.71$ & $59.57 \pm 12.72$ & $91.67 \pm 27.14$ & $76.60 \pm 8.56$ \\
\hline $\mathbf{E}$ & $383.33 \pm 70.33$ & $408.33 \pm 62.48$ & $-6.52 \pm 4.47$ & $450.00 \pm 81.67$ & $-17.39+5.02$ \\
\hline
\end{tabular}

(“-" values considered as 0 in control groups) 
Overall occurrence of GI nematodosis was found to be highest in goats followed by sheep and cattle might be due to different grazing habits. Our findings are slightly similar with the findings of Singh et al., (1999) and Palamapalle et al., (2002). Haemonchus sp. is more prevalent in cattle and sheep while Trichostrongylus in goats have the potential findings in current study. Occurrence of haemonchosis in small ruminants at Budgam district was reported by Bulbul et al., (2010) in case report. Other strongyle nematodes and Trichuris spp. have encountered in the ruminants which affect the economic loss in terms of production and productivity. The occurrence of Trichuris sp. in sheep has been reported by Ahmed et al., (1990) in J\&K state. Khajuria and Kapoor (2003) reported $10.11 \%$ of sheep and $8.11 \%$ of goats infected with Trichuris sp. The faecal sample examinations in the district have not been done before treating the livestock hence non-judicious administration might be another factor for AR which enhance the higher prevalence of the GI nematodosis.

\section{Faecal Egg Count Reduction Test:}

The field trials on effect of some different anthelmentics against GI nematodes in naturally infected ruminants demonstrated significant reduction in the mean faecal egg counts for all the groups of treatment (Table 2). After administration of the different anthelmintic the EPG was found to be in sheep 8.33+8.34, 16.67+10.54, 133.33+16.67, $108.33+35.17$ and $758.33+47.30$; in goat $25.00+11.18, \quad 16.67+10.54,100.00+25.83$, $108.33+35.17$ and $758.33+30.05$ and in cattle $41.67+15.37, \quad 33.33+16.67, \quad 83.33+27.89$, $91.67+27.14$ and $441.67+86.05$ in group A, B, $\mathrm{C}, \mathrm{D}$ and $\mathrm{E}$, respectively. When administered Ivermectin (Inj. Ivomec) @ $200 \mu \mathrm{g} / \mathrm{kg}$ BW subcutaneously, Ivermectin bolus (Endectin) @ $200 \mu \mathrm{g} / \mathrm{kg}$ BW orally, Albendazole suspensions (Albomar) @ 7.5mg/kg BW orally and Fenbendazole (Fentas Bolus) @7.5mg per $\mathrm{Kg} \mathrm{BW}$ orally the FECRT \% was found to be in sheep 98.86+1.04, $97.70+1.42,80.72+2.18,85.71+5.04$; in goats $96.39+1.52, \quad 97.56+1.94, \quad 86.05+3.82$ and $85.06+4.52$ and in cattle 88.37+5.23, $90.00+8.75,79.59+6.67$ and $76.60+8.56$ in group A, B, C and D, respectively on $14^{\text {th }}$ day of post-treatment. In sheep 72.72+3.94, $67.82+4.14,77.11+4.67$ and $78.02+4.99$; in goats $71.08+3.79,68.29+3.22,68.60+3.66$ and $67.82+5.41$ and in cattle $62.79+3.79$, $67.50+8.56,61.24+9.36$ and59.57+12.72 in group $\mathrm{A}, \mathrm{B}, \mathrm{C}$ and $\mathrm{D}$, respectively on $7^{\text {th }}$ day of post-treatment. Almost similar findings were also reported by Ahmed et al., (1990) in Kashmir and various workers from other parts of the country.

This study demonstrated that the tested anthelmintics had an acceptable level of efficacy against GINs in ruminants. But the regular usage of the same group of anthelmintic, use of anthelmintics in suboptimal doses, prophylactic mass treatment of domestic animals and frequent and continuous use of a single drug might be considered to the widespread development of AR in helminthes. Therefore, different groups of anthelmintic used alternatively to reduce the AR as reflected in our present study where ivermectin was more efficacious drugs against GI nematodosis. The gradual reduction of EPG following a single dose of Albendazole and complete elimination of parasitic egg was observed on $14^{\text {th }}$ day of post treatment in calves (Hafiz et al., 2011) unlike our findings. This might be due to attributed of AR. Singh et al., (1994) observed that absence of the parasitic eggs from day 7 to 21 days in Ivermectin (S/C) treated group of sheep and goats. Bansal (1981) reported a reduction of EPG by $99.5 \%$ in Fenbendazole treated animals @ $5 \mathrm{mg} / \mathrm{Kg}$ body weight. Administration of Ivermectin both through $\mathrm{S} / \mathrm{C}$ and orally in endo-parasitism in small 
ruminants was found efficacious (Bulbul et al., 2011). In contrast, animals in control group showed an ascending EPG count were also successfully treated with Ivermectin @ $200 \mu \mathrm{g} / \mathrm{Kg}$ body weight subcutaneously after completion of the trial. From the present study, it can be easily concluded that all three drugs were effective against naturally acquired GI nematodosis in ruminants is an effective anthelmentics against nematodosis in ruminants but resistance arisen might be due to faulty uses. For prevention and control of helminth parasites, appropriate anthelmintic drugs should be administered in right time with right dose in right animals through right route.

\section{References}

Ahmad, M.A, Mir, A.S., Pandit, B.A., and Kirmani, M.A. 1990. Albendazole in the treatment of gastrointestinal nematodes in sheep. J. Vet. Parsitol.4:77-78.

Bansal, S.R., Gautam, O.P., and Deyhazra, 1981. Trials with fenbendazole in natural gastrointestinal nematodiasis in sheep. J. Vet. Parasitol. 20:57-59.

Borthakur, S.K., and Das, M.R. 1998. Epidemiology of gastrointestinal helmiths of dairy animals of Assam. J. Vet. Parasitol. 12: 85.

Bulbul, K. H., Akand, A. H., Ahmed, H. A. and, Medhi, D. 2011. Hitek in the treatment of endo and ecto-parasitism in small ruminants. Environment \& Ecology, 29: 1937-1938.

Bulbul, K. H., Akand, A. H., Ahmed, H. A., and Hafiz, A. 2010. Occurrence of haemonchosis in small ruminants at Budgam district: a case report. Indian J. Field Vet. 6: 23-24.

Bulbul, K. H., Kanth, R. H, and. Sheikh, I. U. 2015. Impact studies for employment generating and skill development technologies based training. Indian $J$. Anim. Prod. Mgmt. 31: 39-43.
Bulbul, K. H., Sheikh, I. U., and Kanth, R. H. 2014. Knowledge level of the livestock farmers on improved husbandry practices in Kashmir valley. Indian $J$. Anim. Prod. Mgmt. 30: 30-34.

Chamuah, J.K., Das, M., and Rajkhowa, S. 2006. Seasonal incidence of gastrointestinal parasites in Mithun. Indian Vet. J. 83:1051-1053.

Coles, G., Bauer, C., Borgsteede, F., Geerts, S., Klei, T., Taylor, M., and Waller, P. 1992.World Association for the Advancement of Veterinary Parasitology (W.A.A.V.P.) methods for the detection of anthelmintic resistance in nematodes of veterinary importance. Vet. Parasitol. 44: 35-44.

Dhar, D. N., and Sharma R.L. 1979. A note on the prevalence of lung worm infection in sheep and goats in Tehsil Kargil of District Ladakh (Jammu and Kashmir). Indian J. Anim. Sci. 49:585588.

Dhar, D. N., and Sharma R.L. 1982. Gastrointestinal nematodes in sheep in Kashmir. Vet. Parasitol. 11: 271-277.

Gupta, R.P., Malik P.D., and Gautam, O.P.1981. The anthelmentic activity of fenbendazole against gastrointestinal nematodes, cestodes and paramphistomes of sheep. Indian Vet. J. 58:246-247.

Gupta, R.P., Ruprah, N.S., and Yadav, C.L. 1986. Some observations on spring rise phenomenon in sheep. Indian Vet. J. 63:449-453.

Gupta, S.C., Bakshi, S.B., Kumar, S., and Singh, J. 1990. Efficiency of ivermctin against naturally acquired nematode infections of sheep. Indian Vet. J. 67:673-674

Hafiz, A., Akand, A. H., and Bulbul, K. H. 2011. Therapeutic efficacy of Albendazole against gastrointestinal nematodes in calves. Indian J. Vet. Med., 6: 33-34. 
Hoste, H., Torres-Acosta, J., and Aguilarcaballero, J. 2008. Parasite interactions in goats: Is immunoregulation involved in the control of gastrointestinal nematodes? Parasit Immun. 30: 79-88.

Kaplan, R. M. 2004. Drug resistance in nematodes of veterinary importance: a status report. Trend Parasitol. 20: 477481

Khajuria, J. K., and Kpoor. P. R. 2003. Prevalence of parasites in sheep and goats at Kathua-Jammu. J. Vet. Parasitol 17(2):121-126.

Makhdoomi, D. M., Shugufta Nasreen, Bandey. S.D., and Moulvi, B. 1995. Incidence of different ovine gastrointestinal parasites in Kashmir. Indian Vet. J. 72: 898-900.

Palamapalle, H.Y., Deshpande, P. D., and Narldkar, B.W. 2002. Gastrointestinal nematodosis in bovines of Marthwada region. J. Vet. Parasitol. 16: 71-72.

Roberts and O'Sullivan (19490. cited by HMSO (1979)

Singh, R.K., Sisoda, R.S. Shukla, P.C., and Pillay, A.G.R. 1999. A note on incidence of gastrointestinal parasites in sheep and goats in Madhya Pradesh. Indian Vet. Med. J. 23:133.

Singh, J., Gill, J. S., Ramneck, and Kwatra, M. S. 1994. Comparative efficacy of anthelmentics against natural nematodes infections of sheep and goats in Punjab. J. Vet. Parasitol. 8: 47-50.

Soulsby, E. J. L.1982. Healminths, Arthropods and Protozoaof domesticated Animals. $7^{\text {th }}$ Edition. Bailliere and Tindall, London.

\section{How to cite this article:}

Kamal Hashan Bulbul, Syed Shanaz Shaf, Dilruba Hasin, Afzal Hoque Akand, Nazir Ahmad and Islam Uddin Sheikh. 2018. Impact of Anthelmintic against Naturally Infected Gastrointestinal Nematodes in Ruminants of Budgam District, Jammu and Kashmir, India. Int.J.Curr.Microbiol.App.Sci. 7(03): 2410-2416. doi: https://doi.org/10.20546/ijcmas.2018.703.280 